\title{
(Un)translatability. Onomastics in Olga Tokarczuk's Primeval and Other Times
}

\author{
(Nie)przekładalność. \\ Onomastyka w powieści Olgi Tokarczuk „Prawiek i inne czasy” \\ Marta BIAEEK ${ }^{1}$ \\ Ateneum-Szkoła Wyższa w Gdańsku
}

\begin{abstract}
Translating culture-specific elements proves to be a challenging task, obliging the translator to refer to his/her extratextual knowledge. Such a necessity is especially noticeable in the case of onomastics which constitutes a vital part of Olga Tokarczuk's novel Primeval and Other Times. Its English translator, Antonia Lloyd-Jones, decided to adopt only a few of translation strategies for proper nouns specified by Andrew Chesterman, which in most instances bereft the source text of its complexity.

Keywords: translation, onomastics, untranslatability, culture-specificity, culture, strategies, Olga Tokarczuk, Antonia Lloyd-Jones odnoszenia się do ich pozatekstowej wiedzy. Taka konieczność jest zauważalna zwłaszcza w przypadku nazw własnych, które stanowią pokaźną część powieści Olgi Tokarczuk „Prawiek i inne czasy”. Jej tłumaczka na angielski, Antonia Lloyd-Jones, zdecydowała się na użycie jedynie kilku strategii tłumaczeniowych wyszczególnionych przez Andrew Chestermana, co w wielu

Słowa kluczowe: przekład, onomastyka, nieprzekładalność, elementy kulturowe, kultura,
\end{abstract}

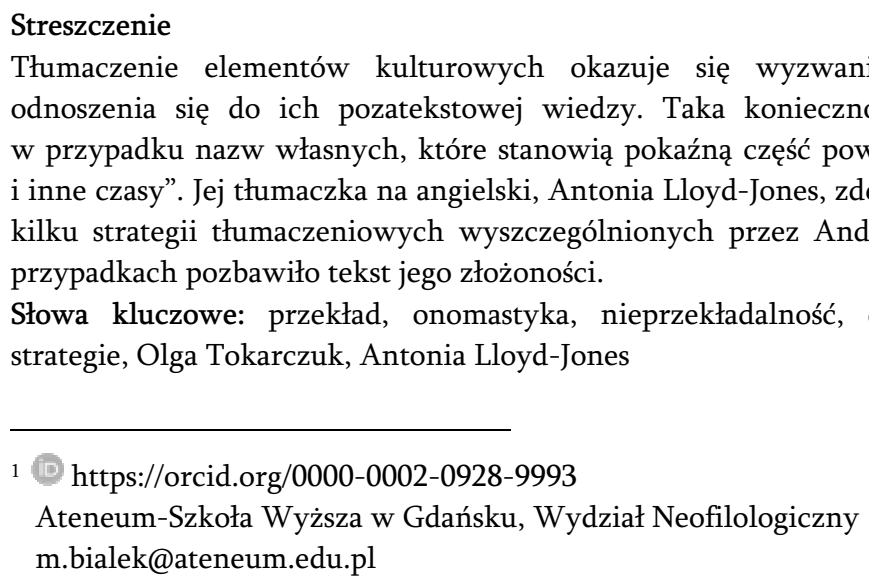
przypadkach pozbawiło tekst jego złożoności. strategie, Olga Tokarczuk, Antonia Lloyd-Jones

1 https://orcid.org/0000-0002-0928-9993

Ateneum-Szkoła Wyższa w Gdańsku, Wydział Neofilologiczny

m.bialek@ateneum.edu.pl 


\section{Introduction}

It is widely known that the task of translating culture-specific elements acts as a determinant of translators' true abilities; nevertheless, what is usually pronounced even more troublesome for the translator is the presence of proper nouns in the source text. There exist terms and expressions so deeply rooted in the source culture, evoking such particular and intricate connotations in their recipients, that their translation proves challenging if not impossible. As a result, allusions are neglected, deeper meanings become lost in translation, and source-text readers' astonishment is replaced by target-text readers' indifference. Therefore, since the final effect evokes little or none of the original feelings, some advocate pronouncing such specific source utterances as entirely untranslatable. However, a question appears - is it always truly a matter of an unspeakably difficult, source culture-oriented text, or rather of an unskilled or inexperienced translator who opts for the application of unoriginal, overfamiliar translational strategies?

In this article, close attention will be paid to the English translation of onomastics - or, in other words, proper nouns - in Olga Tokarczuk's novel Primeval and Other Times. A general, non-detailed typology of translation strategies proposed by Andrew Chesterman will be presented in order to be able to observe and assess particular strategies applied by the translator of the novel, Antonia Lloyd-Jones. Moreover, the definition of untranslatability will be presented to enable deciding whether the translator of Primeval and Other Times, has opted for suitable solutions or - on the contrary $-\mathrm{h}$ as failed to capture the very nature of Tokarczuk's culture-specific elements expressed in the form of proper nouns.

\section{Chesterman's classification of translation strategies}

Pronouncing a given translation proper or insufficient is frequently arbitrary; the number of possible solutions equals the number of points of view. Nevertheless, a range of unified translation strategies must be present so that skilled translators would be able to adopt some of them in their works. There exist numerous lists and divisions of strategies, yet this article will focus on the proposition of Andrew Chesterman.

Interestingly enough, this English scholar observed the need of simplifying the terminology applied in discussions about translation; as he stated, "strategies are ways in which translators seek to conform to norms" 
(Chesterman, 1997, p. 88). Conformity in everyday life may not always prove to be the most optimal solution; however, while working with foreignlanguage text, translators need to adopt a contrary approach which enables them to create consistent utterances - thus norms are demanded. Chesterman (1997) provides an even less complicated definition of translation strategies; for him, the principal rule each translator is bound to follow should be simply to "change something" (Chesterman, 1997, as cited in Owji, 2013). His view on translation strategies implies their fulfilling six primary points: being implemented during translation, changing target texts, being focused on the translational aim, being concentrated around translational problems, being purposefully used by translators and being intelligible not only to the translator but to the target-text readers (Chesterman, 1997, as cited in Owji, 2013). In order to simplify the process of translation even more, Chesterman divided particular strategies into three primary categories: syntactic (alterations of the arrangement of a given term or phrase), semantic (changes of the meaning) and pragmatic (modifications on the level of language in use and the contexts of its use). Each category is then subdivided into ten specific translation strategies concerning particular aspects of a given phrase or term. Syntactic strategies comprise of literal translation, loan/calque, transposition, unit shift, phrase structure change, clause structure change, sentence structure change, cohesion change, level shift, and scheme change. Semantic strategies contain methods such as synonymy, antonymy, hyponymy, converses, abstraction change, distribution change, emphasis change, paraphrase, trope change, and other semantic changes. The last group - pragmatic strategies - is further subdivided into cultural filtering, explicitness change, information change, interpersonal change, illocutionary change, coherence change, partial translation, visibility change, transediting, and other pragmatic changes (Chesterman, 1997, p. 93). Even though a detailed analysis of each possible translation strategy specified by Chesterman will not be presented in this article, attention will be focused on particular translational methods applied by the translator of Primeval and Other Times, Antonia Lloyd-Jones. Each of them will be described and ascribed to a more general category, revealing a pattern (or lack of thereof) of translator's choices.

\section{Translation of proper nouns in Primeval and Other Times}

Primeval and Other Times, the third novel in Tokarczuk's literary output, nominated for the title of Book of the Year 1996 in The Nike Literary Award 
contest (Skibińska, 2000, p. 158), abounds in proper nouns referring to both nature and religion. It is a characteristic feature of the writer's style, present equally in her older and newer novels; philosophical dimension of her narrative is prevalent, as is a constant urge to find universal truths about life. The standard order of the world is reversed; plants and animals become subjectified, children possess the deepest understanding of rules regulating the order of matters, and adults oftentimes lose their logical assessment, following pure instincts and desires (Marciszuk, 2008). Additionally, Tokarczuk's literary world abounds in elements of both magic and reality, with some events being shaped by human fantasy and the others by the power of knowledge. By basing her narrative on this very dualism, Tokarczuk helps the readers acknowledge what they fear the most (Marciszuk, 2008).

The analysed examples of proper nouns from Primeval and Other Times will comprise of anthroponyms (proper nouns describing people and extraterrestrial, humanoid beings), phytonyms (names of plants), as well as genderoriented proper nouns which might occur the most troublesome for the translator.

\subsection{Anthroponyms}

The first group of proper nouns which constitutes one of the most visible parts of the novel are anthroponyms referring to religion and nature. Interestingly enough, Tokarczuk either employs the strategy of naming some of the characters of Primeval and Other Times after animals and celestial beings, or she incorporates religious references into their names. The main character's surnames are inter alia Ukleja (which literally translates into English as bleak), Papuga (parrot in English), Cherubin (cherub), Serafin (seraph), Boski (heavenly), and Niedziela (Sunday). Strikingly, none of these was translated into English; using the classification proposed by Chesterman (1997), Antonia Lloyd-Jones opted for a strategy reverse to Chesterman's cultural filtering (implying domestication of terms), which in this instance might be named foreignisation (Chesterman, 1997). One can argue that leaving a name or surname - even a meaningful one - foreignised is a commonly applied technique. Nevertheless, these examples undoubtedly illustrate how massive role is played by the very sound and appearance of a word in the process of creating associations. For the Polish reader, words such as papuga or ukleja evoke images of these specific animals; serafin and cherubin denote heavenly beings, whereas boski and niedziela both refer to religion and religious ceremonies (as in Catholicism, people attend churches every Sunday). 
However, as one can observe, the English terms cherub and seraph are almost the same in form and sound as their Polish counterparts. It is then highly possible that English readers will not only understand but also associate these surnames with more or less the same images as the recipients of the source text, even if the form of the words is retained. Nevertheless, by keeping the original appearance of Papuga, Ukleja, Boski, and Niedziela - namely by foreignising them - Lloyd-Jones deprived the target-text recipients of immediate associations with nature and religion. Where source-text readers see a subtle reference to the natural and religious worlds, the English ones receive merely a confusing, foreign-looking term.

Strikingly, a different strategy was applied by the translator with another example of anthroponym - Kłoska. In English translation, this character's name (or rather nickname) was rendered as Cornspike; thus a neologism was created (combining the words corn and spike). According to Chesterman's classification of translation strategies, such an undertaking is known as trope change the figurativeness of expression is retained, yet the very structure of the term is different (Chesterman, 1997). One may wonder why Lloyd-Jones has opted for translating this name while leaving the others intact; the only reason behind her choice must be the fact that Cornspike functions in the text as a nickname rather than a full, proper surname or name. Tokarczuk does not provide much information about this very character in the novel; thus the application of such strategy may be justified by the distinct nature of this term. As a result, English-text recipients are capable of noticing that Cornspike's relation with the natural world in the novel is expressed not only through her actions but also through her name. It is unfortunate, though, that they cannot observe such a connection while discovering other characters' surnames.

As previously mentioned, Primeval and Other Times abounds in references to magical, non-terrestrial beings and phenomena. One of such creatures described by Tokarczuk might be Topielec Pluszcz, a mystical phantom which - among others - constitutes a personification of magic intertwined with the everyday world. This example also indicates how even a seemingly short phrase may force translators to apply more than one translation strategy. In this very case, Antonia Lloyd-Jones opted for both literal translation and distribution change, as specified by Chesterman (1997). Firstly, Pluszcz was translated as Dipper, evoking the same connotations in both Polish and English readers, since this is a literal translation of the name of a specific bird. However, the other part of the name was tackled differently, as topielec in Polish indicates someone who drowned. By adopting the strategy 
of distribution change (Chesterman, 1997), Lloyd-Jones was able to expand the given semantic component into more elements, creating the expression The Drowned Man. Interestingly enough, such a procedure allowed her to retain the sound instrumentation present in the source text - the very word pluszcz has a rather specific sound in Polish, yet the term dipper does not seem to illustrate it using the same force. However, combining all the elements and creating the name Dipper the Drowned Man proved to be a somewhat successful undertaking, as the target-text reader immediately notices the used alliteration. Even though the final result is longer than the original, Lloyd-Jones managed to capture the rhythm of the source-text phrase.

\subsection{Phytonyms}

Since natural world and religion both constitute a significant part of Primeval and Other Times, there is no doubt why Tokarczuk decided upon using particular phytonyms which either refer to the heavenly sphere or act as characters in the novel. The first example of such a proper noun might be the specific species of flower, which in Polish is mniszek. In its appearance, this word resembles a diminutive form of the term mnich, which in English would be monk. Even though the connotation might not be evident at first glance, still the source-text recipients are able to notice the reference to the religious sphere. In the English translation of Primeval and Other Times, Antonia LloydJones chose the term dandelion to render the meaning of mniszek, incorporating the strategy of literal translation (Chesterman, 1997). There is no doubt that this very strategy proves to be the most accurate since dandelion is the exact equivalent of the word mniszek. Nevertheless, the religious aspect of this term is irrevocably lost, as the English translation does not evoke any particular image in the recipients. It would be nonsensical to blame the translator for the lack of equivalent referring to religion (even the Latin name of dandelion is Taraxacum); still, the loss of additional association in the target text deprives its readers of the original picture.

The following example of phytonym proves to be even more associated with religion, as its Polish name presented in the novel is kwiatki świętej Małgorzatki. Traditionally, such a flower is named margerytka or jastrun in Polish, which might be translated into English as oxeye daisy or moon daisy. One might wonder why Tokarczuk opted for the application of the diminutive forms kwiatki and Małgorzatki; moreover, this very name is rather rarely employed by the speakers of Polish themselves. The only reason for the presence of such a term in the novel must be the fact that it also illustrates 
the connection between the respect for nature and religion expressed more often than not by people living in the villages. The very form of the term kwiatki świętej Małgorzatki might suggest it is deeply rooted in folk culture, thus both unique and not commonly applied by the source-language speakers. Lloyd-Jones decided to translate this phytonym into English as St Margaret's daisies, opting for the strategy named by Chesterman as hyponymy (Chesterman, 1997). She, therefore, changed the hyponym oxeye or moon daisy into a superordinate daisy, bereaving the source term of its specificity. The other part of the phytonym - świętej Małgorzatki - was rendered as St Margaret's, which is understandable, as diminutive forms are not as common as they are in Polish; therefore, the strategy of literal translation was applied (Chesterman, 1997). Regrettably, a subtle rhyme was also lost in translation, as the Polish word kwiatki rhymes with Małgorzatki; nevertheless, such a translation might be considered accurate enough, as both source and target terms preserve the exoticness and folksiness of their forms.

Another interesting example of a phytonym used by Tokarczuk is the word arcydzieggiel, which was translated into English as masterwort. This very instance illustrates a captivating issue that is applying (or refraining from doing so) Latin names to translated items instead of target-language equivalents. Even though Lloyd-Jones did not opt for such a solution, perhaps it would prove the most optimal, as the Latin name of arcydzieggiel used in English is Angelica archangelica. It is then immediately noticeable that such a choice would more likely than not compensate for all the other translational losses of religious connotations in the target text. Still, the translator of Primeval and Other Times decided upon the application of the term masterwort, which surprisingly - in back-translation into Polish would be gorysz miarz. Such a strategy could be named synonymy (Chesterman, 1997), as regardless of the similarities between those two plants, they are distinct from each other. It is uncertain why Lloyd-Jones refrained from translating this term using its Latin counterpart; one may assume that the reason was its foreign form which might have deterred target-text readers. However, as it was stated before, such a solution may have proven to be an appreciable act of compensation for previous inconsistencies.

\subsection{Gender-oriented proper nouns}

There exist such aspects of languages that seem more troublesome to translate than others; one of them is undoubtedly the notion of gender in Polish. Each of the proper nouns discussed above possesses its gender, none of which being 
too crucial for the comprehension of the target text. Nevertheless, the examples which are bound to be presented prove that in specific instances, the process of translation is significantly inhibited by the distinctiveness of some expressions based on their grammatical gender. Jerzy Jarniewicz (2012) describes it as the so-called 'gender untranslatability', a phenomenon occurring when the gender determines the context of an utterance to such an extent that it prevents the translators from applying synonymous expressions (Jarniewicz, 2012, p. 76). Writer's playing with the notion of gender, though undoubtedly enriching the original text, more often than not proves to be highly troublesome for translators whose target languages are deprived of such aspect or use it to a far less extent than source one.

In Primeval and Other Times, Tokarczuk decided to incorporate the grammatical notion of gender in a rather stupefying manner. It is certain that all nouns in Polish are either masculine, feminine or neuter, yet usually, it affects the tone of neither the source text nor the target text. In the majority of instances, such evident yet natural is the existence of grammatical gender, that Polish readers would not even notice it is an inherent part of a given term. However, being an advocate for nature's force and importance in the world, Tokarczuk reversed the traditional order of matters and devised such proper nouns which humanise dogs and cats. Therefore, the readers are presented with terms such as psowie and kotowie, both of them constituting examples of the plural masculine gender (instead of being traditionally plural non-masculine). By incorporating such a change, strikingly apparent for the source-text recipients, the writer broke the existing rules of Polish grammatical gender, creating unique utterances which automatically oblige to change perspective. Antonia Lloyd-Jones, the translator of Primeval and Other Times, rendered these terms into English as $m r \operatorname{dog}$ and $m r$ cat, applying two translation strategies - phrase structure change (based on changing the form of a noun from singular to plural) and interpersonal change (incorporating the title $\mathrm{mr}$ before each noun) (Chesterman, 1997). It does not seem to be an unskilfully performed translation; however prominent in Polish, grammatical gender in English is almost nonexistent; thus it would be unfair to demand from Lloyd-Jones to create some unreadable terms. Nevertheless, in Polish the notion of the gender of nouns is inextricably linked with the form of verbs used to describe their actions; in Primeval and Other Times, the change of gender also forced the alteration of preceding verbs, since the grammatically correct phrase psy położyły się became psowie położyli się in the novel. Though it is evident for the Polish reader, the English one will be still presented with the very same verb form (regardless of whether a dog or $\mathrm{mr} d o g$ 
is used, the verb form will always be laid down). On the one hand, Lloyd-Jones managed to retain the distinctiveness of these nouns; on the other, however, they still prove to be more striking and unnatural in the source text.

Another example of Tokarczuk's play with the notion of grammatical gender might be the expression used by one of the youngest characters of the novel, who pondered upon the nature of religion. His though process resulted in creating an utterly new for God, which in Polish took the form of Bożyca. It is another instance of Tokarczuk altering the grammatical gender of the word from the usual masculine Bóg to feminine Bożyca; inventing such a term allowed the writer to alter the perspective of Polish readers, as, when one takes into consideration the grammatical gender, religion seems rather masculine-oriented. Nevertheless, the translator of Primeval and Other Times was forced to face yet another translational obstacle, since, as it was stated before, the grammatical gender of nouns is almost nonexistent in English. Antonia Lloyd-Jones opted for the inventive solution of rendering the source term into the target language as She-God. According to Chesterman (1997), such a strategy may be named distribution change - or, more precisely expansion, a process when the same semantic component becomes translated with the use of more items (Chesterman, 1997). Similarly to the aforementioned examples, there is not much to criticise in this very instance; although the original term might seem slightly more unusual for the sourcetext recipients, still its target-language counterpart also proves to be striking and unheard-of. Bearing in mind that the translator was bound to perform such a troublesome task of conveying the same amount of feeling and information while also being bereft of the same grammatical notion, one has to agree that Lloyd-Jones managed to grasp the spirit of these particular terms.

It is crucial to also remember about the third possible grammatical gender in Polish, namely the neuter. The final examples which will be discussed in this article are all representatives of this very gender, simultaneously following a distinct, unusual pattern. When the aforementioned young character of Primeval and Other Times deliberated about religious issues, he invented yet another term for God, namely Boże. Interestingly enough, this is not a new or uncommon proper name in Polish, as its speakers are well acquainted with this utterance. Nevertheless, what became altered here was the case of this noun - it changed from there usual vocative (as uttered by those speaking directly to God) to nominative, replacing the usual Bóg. One might ponder about the reason for such an alteration; Tokarczuk's character dreamed about de-gendering the word Bóg, leaving it 
neither masculine nor feminine. To support his idea, he developed a complete list of terms which shared the same neuter grammatical gender with the word Boże. They included: Boże, słonce, powietrze, miejsce, morze, zbozè, ciemne, jasne, zimne, ciepłe, zawsze, pozywienie, wszędzie and nigdzie. As one can observe, they all end with vowel $e$, as the majority of Polish neuter words does; not only is the pattern noticeable while looking at them, it is also apparent for the source-text readers immediately after they realise the grammatical gender applied. Thus a skilful translator should be capable of rendering both aspects of this set of utterances, namely the grammatical gender and the visual similarity. Having no English counterpart for the notion of gender, Antonia Lloyd-Jones opted for preserving the visual representation of applied strategy, translating the terms respectively: O-God, oak tree, opal, ocean, odour, oatmeal, omen, open, - , -, over and over, unique and unrepeatable (only), omega, n-owhere. According to Chesterman's (1997) typology of translation strategies, this very concept might be called scheme change, a strategy allowing the translator to adopt a specific scheme over an already existing one or to invent a new scheme in instances when the source text did not provide any (Chesterman, 1997). It is noticeable that in this very example Lloyd-Jones applied alliteration, starting all the words by the vowel $o$, as if compensating for the loss of final $e$ in all neuter Polish words. Interestingly enough, the translator managed to retain the original meaning of the first term, Boże, as the translation $O-G o d$, when read aloud, sounds precisely alike as the Polish vocative case. Examining the English words closely, one can observe that some of them are instances of literal translation or synonymy (ocean, oatmeal, omega, n-owhere); the rest, even if greatly significantly from the source text, still retains the inventive pattern of alliteration. Even though Lloyd-Jones failed to provide counterparts to two of the enumerated words, still she managed to capture the graphic representation of the distinctiveness of these terms.

\section{The notion of untranslatability}

The analysed examples from the novel enable to establish a specific pattern of Lloyd-Jones's approach towards translating proper nouns. Nevertheless, before doing so, one more theoretical notion must be presented here in order to be able to state clearly whether or not in Primeval and Other Times exist terms and phrases which one might describe as untranslatable - and, if so, 
whether certain seemingly incorrect translational choices in the novel may be justified.

A prevailing assumption in the field of translation would be the one which suggests that there always exists a possibility of rendering all terms and notions into a given target language, regardless of them being culturespecific or simple. Following this belief, the recipients of the target text would then become acquainted with more or less spectacular effects of translators' work, yet they would still obtain what could be named as translation. Nonetheless, dissatisfaction may occur when target-text readers realise that a given translator was obliged either to remain faithful to the source text, creating obscurity or ambiguity, or to domesticate the original concepts, making them perfectly understandable for the recipients, yet losing the original exoticness.

As it may be inferred, such solutions usually prove to be inadequate and faulty, conducing to inevitable losses in translation. Moreover, practice shows that both experienced and novice translators encounter instances when a concept existing behind a given term seems entirely untranslatable. Such concepts may vary from cultural symbols, religious aspects, linguistic means (proverbs, metaphors or grammar) to relations with other nations, and intertextuality (Bałuk-Ulewiczowa, 2000, p. 177). Interestingly enough, there exists a definition of untranslatability which might be referred to anytime one wishes to check whether the improper translation occurred because of translator's pure misunderstanding of a given concept or because the said concept may be named untranslatable. As Teresa Bałuk-Ulewiczowa puts it, "absolute untranslatability occurs whenever a text is presented for translation the full comprehension of which by its source-language recipients requires the application of extra-textual subjective information or, more generally, extra-textual emotional experience which is inaccessible to the recipients of the target language for the translation." (Bałuk-Ulewiczowa, 2000, p. 173).

Acquainted with the theory concerning untranslatability, one might pose a question about whether or not Antonia Lloyd-Jones, the translator of Primeval and Other Times, encountered such instances of proper nouns and culture-specific elements that their rendition into English with the use of Chesterman's strategies proved unattainable. The first example that might be connoted is the notion of grammatical gender in Polish which emanated itself in the neologisms psowie and kotowie, as well as in the forms of the verbs that followed. Almost entirely deprived of such concept in their mother tongue, the speakers of English are unable to recreate the very same feeling of 
foreignised structures which is present in the source text. Moreover, what may be defined as untranslatable are the phytonyms referring to religious sphere, such as mniszki or kwiatki świętej Małgorzatki. Due to their rather specific folk nature, it is highly troublesome if not impossible to translate them preserving the very same extra-textual emotional attitude. However, all other examples presented in this article proved to be at least partially translatable, even if oftentimes the choice of particular strategies seemed questionable.

\section{Conclusions}

The aforementioned examples of proper nouns from the novel Primeval and Other Times allow observing a variety of translation strategies specified by Chesterman (1997) and applied by Lloyd-Jones. Interestingly enough, even though the methods from all three categories were employed with almost the same frequency, two groups of strategies prevail when compared to others these are both syntactic and semantic strategies. The former, comprising of changing the arrangement of words and phrases, was applied four times in translation of anthroponyms, phytonyms and gender-oriented proper nouns; the latter, focused on meaning, is present whenever Lloyd-Jones was rendering the anthroponyms and phytonyms into their English counterparts, which also happened in four instances. The third category of translation strategies, namely pragmatic changes (those implying language in use and the contexts in which it is used), was adopted two times in the cases of anthroponyms and genderoriented proper nouns.

It seems clear that it would be impossible to opt for just one category of translation strategies; as complex and intricate as languages are, they constitute a net of intertwined parts and meanings. One is unable to focus purely on their semantics and disregard the syntax, and vice versa; therefore, translators seem somehow obliged to adopt a mixture of all possible categories of strategies. However, examples discussed in this article indicate that Antonia Lloyd-Jones more often than not failed to grasp and accurately convey the source-text meanings. Though perfectly noticeable for the target-text readers, cultural references disappeared in the translation, as did exoticness and folksiness of some expressions; moreover, nature and animals seem quite powerless compared to their Polish counterparts.

Taking into consideration the entirety of the novel and the intricacies of the Polish language, one might argue that Lloyd-Jones's task was almost impossible. Nevertheless, specific instances prove that just a little more 
explanation or change of perspective was needed in order to achieve quite a decent outcome. When asked about her occupation and difficulties of the process, Antonia Lloyd-Jones stated that she always regards translation as a compromise between being faithful both to the author and to the reader (Lloyd-Jones, 2006, p. 110). It seems, however, that compromises in translation serve well neither the former nor the latter.

\section{REFERENCES}

Bałuk-Ulewiczowa, T. (2000). Beyond cognizance: fields of absolute untranslatability." In: Przekładając Nieprzekładalne, I. Kubińska O., Kubiński W., Wolański T. Z. (Eds.). Vol. 1. (pp. 171-180). Gdańsk: Wydawnictwo Uniwersytetu Gdańskiego.

Chesterman, A. (1997). Memes of Translation. The Spread of Ideas in Translation Theory. Amsterdam: John Benjamins Publishing Company.

Jarniewicz, J. (2012). Gościnność słowa: szkice o przekładzie literackim. Kraków: Wydawnictwo Znak.

Lloyd-Jones, A. (2006).“ Przekład jako kompromis: garsć uwag o tłumaczeniu prozy Pawła Huellego i Olgi Tokarczuk.” Poezja i proza przekładu. Przekładaniec: a Journal of Literary Translation. Edited by Magda Heydel. Vol. 17. (pp. 109-123). Kraków: Tertium.

Marciszuk, P. (2008). Literatura, filozofia, mit. Warszawa: STENTOR.

Owji, Z. (2013). Translation Strategies: A Review and Comparison of Theories. Translation Journal. Vol. 17/2013. Retrieved June 20, 2020 from https://ranslationjournal.net/ journal/63theory.htm.

Skibińska, E. (2000). Nazwy własne we francuskim przekładzie Prawieku i innych czasów Olgi Tokarczuk. In: Przekładając Nieprzekładalne I. Kubińska O., Kubiński W., Wolański T. Z. (Eds.). Vol. 1. (pp. 155-166). Gdansk: Wydawnictwo Uniwersytetu Gdańskiego.

Tokarczuk, O. (1996). Prawiek 1 inne czasy. Warszawa: Wydawnictwo Literackie.

Tokarczuk, O. (2010). Primeval and Other Times. (A. Lloyd-Jones, Trans.). Prague: Twisted Spoon Press. Original work published 1996. 
